\title{
Implementasi Sistem Surveillance Berbasis Pengenalan Wajah pada STMIK STIKOM Indonesia
}

\author{
I Nyoman Tri Anindia Putra a1, Evi Dwi Krisna a2 \\ aTeknik Informatika, STMIK STIKOM Indonesia \\ Jalan Tukad Pakerisan No. 97 Denpasar, Indonesia \\ ${ }^{1}$ trianindiaputra@gmail.com
}

\begin{abstract}
Abstrak
Sistem pengenalan wajah manusia merupakan salah satu bidang yang cukup berkembang dewasa ini, dimana aplikasi dapat diterapkan dalam bidang keamanan (security system) seperti ijin akses masuk ruangan, pengawasan lokasi (surveillance), maupun pencarian identitas individu pada database kepolisian. Penelitian ini bermaksud untuk merancang bangun sistem surveillance berbasis pengenalan wajah dengan menggunakan metode pengenalan wajah yang berfokus pada jarak dan akurasi dari pendeteksian wajah melalui kamera yang dapat dikenali melalui metode haarcascade classifier. Hasil dari penelitian dengan menggunakan metode tersebut memperoleh rata rata deteksi wajah dengan jarak maksimal adalah 3 meter dari kamera. Sedangkan hasil untuk akurasi pengenalan wajah dengan metode eigenface dan haarcascade classifier masing masing memperoleh akurasi 1 meter sebesar 87\%, 2 meter sebesar 83\%, dan 3 meter sebesar $63 \%$.
\end{abstract}

Keywords: Surveillance, Haarcascade Classifier, Eigenface,

\section{Abstract}

The human face recognition system is one of the most developed fields today, in which applications can be applied in the security sector, such as room entry permits, location surveillance, and search for individual identities in police databases. This study intends to design a facial recognition-based surveillance system using facial recognition methods that focus on the distance and accuracy of face detection through a camera that can be recognized through the haarcascade classifier method. The results of the study using this method obtained an average face detection with a maximum distance of 3 meters from the camera. Meanwhile, the results for facial recognition accuracy with the eigenface and haarcascade classifier methods each obtained an accuracy of 1 meter by $87 \%, 2$ meters by $83 \%$, and 3 meters by $63 \%$.

Keywords: Surveillance, Haarcascade Classifier, Eigenface

\section{Pendahuluan}

Sistem pengenalan wajah manusia merupakan salah satu bidang yang cukup berkembang dewasa ini, dimana aplikasi dapat diterapkan dalam bidang keamanan (security system) seperti ijin akses masuk ruangan, pengawasan lokasi (surveillance), maupun pencarian identitas individu pada database kepolisian. Kemajuan teknologi membuat penggunaan video surveillance di beberapa ruangan semakin penting guna meningkatkan keamanan dan privasi bagi penggunanya. Adanya video real-time yang berfungsi merekam suatu gambar pada suatu kegiatan tentu penting bagi beberapa instansi seperti perbankan, perkantoran, pertahanan negara, dan lain-lain. Pengenalan wajah adalah salah satu sistem identifikasi yang dikembangkan berdasarkan perbedaan ciri wajah seseorang berbasis biometric yang memiliki keakuratan tinggi[1]. 
Berdasarkan hasil observasi yang sudah dilakukan di Kampus STMIK STIKOM INDONESIA yang akrab disebut STIKI sering terjadi permasalahan terkait kenyamanan dan keamanan penggunaan fasilitas kampus yaitu, 1) mahasiswa yang terlalu kreatif sering melakukan corat-coret pada meja lab komputer, 2) memasang stiker pada lab komputer, 3)merubah tombol key pada keyboard, 4) sampai dengan mencabut semua kabel komputer sehingga komputer tidak dapat digunakan sebagaimana mestinya. Fenomena ini tentunya dapat mengurangi kenyamanan pada proses belajar mengajar saat perkuliahan berlangsung dan akan berdampak pada proses belajar mengajar perkuliahan berikutnya. Walaupun di setiap ruangan kampus dilengkapai dengan Closed Circuit Television (CCTV) pengidentifikasian personal masih sulit dilakukan.

Oleh karena itu, diperlukan sistem surveillance berbasis pengenalan wajah untuk mencegah dan menanggulangi tindakan dari oknum yang tidak bertanggung jawab. Metode pengenalan wajah yang digunakan dalam penelitian ini adalah Eigenface dan Distance Classifier yang mana, metode ini merupakan metode yang sering digunakan untuk proses pengenalan wajah serta memiliki proses pengenalan wajah yang cepat dan akurasi yang cukup Berdasarkan hal tersebut diperlukan suatu sistem surveillance yang mampu meningkatkan keamanan yang ada pada suatu tempat serta mampu mengenali personal secara realtime. Pada penelitian ini berfokus pada implementasi sistem surveillance berbasis pengenalan wajah yang mampu mengidentifikasi personal. adapun pengujian yang dilakukan pada penelitian ini yaitu pengujian jarak maksimal dari metode haarcascade dalam mendeteksi wajah dan mengetahui tingkat akurasi pengenalan wajah melalui metode pengenalan wajah yaitu eigenface yang dikombinasikan dengan metode euclidian distance berdasarkan jarak tertentu.

\section{Metode}

Adapun metode yang digunakan diantaranya adalah metode pengenalan citra wajah berhubungan dengan obyek yang tidak pernah sama, karena adanya bagian- bagian yang berubah. Perubahan ini dapat disebabkan oleh ekspresi wajah, intensitas cahaya dan sudut pengambilan gambar, atau perubahan asesoris pada wajah. Dalam kaitan ini, obyek yang sama dengan beberapa perbedaan tersebut harus dikenali sebagai satu obyek yang sama. Selain itu metode Euclidean Distance adalah metode yang sering digunakan untuk menghitung jarak antara 2 vektor. Euclidean Distance digunakan untuk mengklasifikasi data (feature vector). Euclidean distance menghitung akar dari kuadrat perbedaan 2 vektor [2].

Pengenalan pola (Pattern Recognition) adalah bidang ilmu yang digunakan pada penelitian ini yang melakukan proses analisis Gambar yang inputnya adalah Gambar ataupun citra digital dan menghasilkan output suatu deskripsi dengan tujuan untuk mendapatkan informasi yang disampaikan oleh Gambar atau citra, dengan kata lain meniru kemampuan manusia (Otak manusia ) dalam mengenali suatu objek atau pola tertentu [3].

Metode LDA lebih optimal untuk melakukan diskriminasi atau klasifikasi dibandingkan dengan PCA yaitu dengan memaksimalkan rasio penyebaran antar kelas terhadap penyebaran dalam kelas untuk memudahkan klasifikasi sehingga fisherface dapat digunakan pada dataset wajah dengan variasi yang besar [4] akan tetapi metode PCA memiliki Kecepatan yang lebih baik dibandingkan dengan LDA [5].

Sistem absensi mampu melakukan proses absensi kepada user secara realtime dengan metode $\mu$ melalui pengujian secara fungsional akan tetapi Akurasi pada sistem absensi melalui metode pengenalan wajah ini akan semakin buruk jika pencahayaan kurang atau lebih [6]. Deteksi wajah menjadi point yang sangat penting dalam suatu sistem absesnsi wajah. pada penelitian ini metode deteksi wajah yang digunakan adalah metode haarcascade classifier. metode ini memiliki pendekatan dalam mendeteksi dengan cara menggabungkan empat kunci utama yaitu Haar Like Feature, Integral Image, Adaboost learning dan Cascade classifier [7].Cascade classifier adalah sebuah metode untuk mengkombinasikan classifier yang kompleks dalam sebuah struktur bertingkat yang dapat meningkatkan kecepatan pendeteksian obyek dengan memfokuskan pada daerah citra yang berpeluang saja [7]. berikut merupakan struktur dari metode haar cascade classifier. 


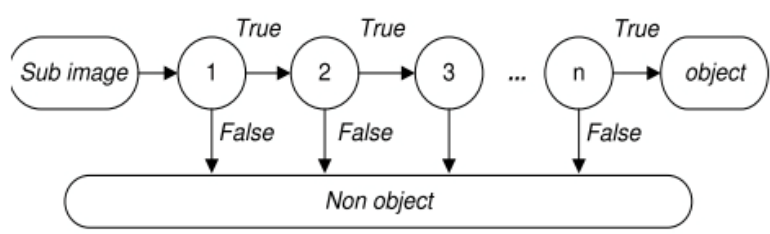

Gambar 1. Struktur Metode Haar Cascade Clasifier

Haar Like Feature adalah selisih atas jumlah citra piksel dari daerah di dalam persegi panjang. Nilai Haar Like Feature diperoleh dari selisih jumlah nilai piksel daerah gelap dengan jumlah nilai piksel daerah terang :

$$
\mathrm{F}(\text { Haar })=\sum \mathrm{F}_{\text {White }}-\sum \mathrm{F}_{\text {Black }}
$$

$\mathrm{F}($ Haar $)=$ Nilai fitur total

$\sum F_{\text {White }}=$ Nilai fitur pada daerah terang

$\sum \mathrm{F}_{\text {Black }}=$ Nilai fitur pada daerah gelap

Integral Image merupakan teknik menghitung nilai fitur yang cepat dengan cara mengubah nilai setiap piksel menjadi representasi citra baru. citra integral pada titik $(x, y)(i i(x, y))$ dapat dicari menggunakan persamaan

$$
\operatorname{ii}(x, y)=\sum_{x^{\prime} \leq x}, y^{\prime} \leq y\left(x^{\prime}, y^{\prime}\right)
$$

Keterangan

$\mathrm{ii}(\mathrm{x}, \mathrm{y})=$ Citra integral pada lokasi $\mathrm{x}, \mathrm{y}$

$\mathrm{i}\left(\mathrm{x}^{\prime}, \mathrm{y}^{\prime}\right)=$ nilai piksel pada citra asli

Algoritma Adaboost learning, digunakan untuk meningkatkan kinerja klasifikasi dengan pembelajaran sederhana untuk menggabungkan banyak classifier lemah menjadi satu classifier kuat. Classifier lemah adalah suatu jawaban benar dengan tingkat kebenaran yang kurang akurat [8]. Sebuah classifier lemah dinyatakan:

$$
\mathrm{h}_{\mathrm{j}}(\mathrm{x})=\left\{\begin{array}{lr}
1, & \text { jika } \mathrm{p}_{\mathrm{j}} \mathrm{f}_{\mathrm{j}}(\mathrm{x})<\mathrm{p}_{\mathrm{j}} \theta_{\mathrm{j}}(\mathrm{x}) \\
0, & \text { lainnya }
\end{array}\right.
$$

Langkah selanjutnya adalah menormalkan bobot sehingga $\mathrm{w}_{\mathrm{t}}$ adalah distribusi probabilitas

$$
w_{t, i} \leftarrow \frac{w_{t, i}}{\sum_{j=1}^{n} w_{t, j}}
$$

untuk setiap fitur, j melatih classifier $h_{j}$ untuk setiap fitur tunggal. selanjutnya kesalahan dievaluasi dengan bobot $\mathrm{w}_{\mathrm{t}}$.

$$
\epsilon_{j}=\sum_{i} w_{i}\left|h_{j}\left(x_{i}\right)-y_{i}\right|
$$

pilih classifier $h_{t}$ dengan eror terkecil dimana $e_{i}=0$ untuk $x_{i}$ adalah klasifikasi benar, dan $e_{i}=1$ untuk yang lain kemudian dilakukan pembaharuan bobot dimana :

$$
\begin{gathered}
w_{t+1, i}=w_{t, i} \beta_{t}^{1-e_{i}} \\
\beta_{t=\frac{\epsilon_{t}}{1-\epsilon_{t}}}
\end{gathered}
$$

Sehingga diperoleh suatu classifier kuat yaitu

$$
\begin{aligned}
& \mathrm{h}(\mathrm{x})= \begin{cases}1, & \sum_{\mathrm{t}=1}^{\mathrm{T}} \alpha_{\mathrm{t}} \mathrm{h}_{\mathrm{t}}(\mathrm{x}) \geq \frac{1}{2} \sum_{\mathrm{t}=1}^{\mathrm{T}} \alpha_{\mathrm{t}} \\
0, & \text { lainnya }\end{cases} \\
& \text { dimana } \alpha_{\mathrm{t}}=\log \frac{1}{\beta_{t}}
\end{aligned}
$$

Eigenface melakukan proses reduksi dimensi saat citra dimasukan kedalam suatu subruang saat dilakukan proses training. Subruang dalam hal ini adalah dimensi yang paling rendah dimana menggambarkan eigenface ditemukan saat training. langkah langkah saat ekstraksi ciri menggunakan metode eigenface yaitu pertama [9] : 
1. Menentukan Data dalam bentuk himpunan yang terdiri dari seluruh citra data latih $(\Gamma 1$, $\Gamma 2, \ldots, \Gamma \mathrm{M})$. dalam penentuannya dibuat himpunan citra (S) berdasarkan total M citra latih. Dimana pada setiap data citra merupakan $\mathrm{p}$ x q piksel.

$$
S=\{\Gamma 1, \Gamma 2, \ldots, \Gamma M\} .
$$

2. Mengambil nilai tengah atau rerata, menggunakan perhitungan rerata flatvector matriks citra tentunya dengan menjumlahkan seluruh data citra pelatihan yang selanjutnya dibagi dengan jumlah himpunannya.

$$
\psi=\frac{1}{M} \sum_{N=1}^{M} \Gamma n 1
$$

3. Selanjutnya mencari selisih antara citra latih dengan nilai tengah. Hasil rerata digunakan dalam pencaharian selisih dari citra latih dan nilai rata-rata. jika bernilai minus akan dianggap 0 .

$$
\Phi i=\Gamma 1-\Psi
$$

4. mencari nilai matriks kovarian (C) dengan cara mengalikan selisih dengan melakukan matriks transpos.

$$
C=\frac{1}{M} \sum_{n=1}^{M} \Phi n \Phi_{n}^{T}
$$

5. menghitung eigenvalue, eigenvector dan matriks kovarian $(C)$ menggnakan

$$
C x v i=\lambda i x v i
$$

6. setelah mendapatkan nilai dari eigenvector, selanjutnya eigenface dapat dicari dengan cara

$$
\mu i=\sum_{k=1}^{M} \text { vi } x \Phi k, 1=1, \ldots M \text {. }
$$

7. Proses untuk identifikasi dari ekstraksi ciri citra wajah dilakukan dengan cara citra baru dalam hal ini adalah citra pengujian, dilakukan proses pengenalan dengan melakukan tahapan perhitungan eigenface untuk mendapatkan nilai dari eigenvalue dari citra tersebut.

$$
\mu_{\text {new }}=v .(\text { Гnew. } \psi), \Omega=\left[\mu_{1}, \mu_{2}, \ldots, \mu_{m}\right]
$$

8. dan selanjutnya menggunakan metode jarak ketetanggaan terdekat untuk menentukan citra yang dikenali yaitu metode euclidian distance.

$$
\varepsilon k=\Omega-\Omega k
$$

Penelitian dilakukan dengan beberapa tahap, yang pertama analisis dan permasalahan dan kebutuhan dalam merancang bangun sistem surveillance berbasis pengenalan wajah akan dilakukan oleh Ketua peneliti. Tahap kedua melakukan studi pustaka dimana ketua peneliti mencari referensi terkait dengan penelitian yang akan dibuat. Tahap ketiga ketua peneliti melakukan desain sistem dan database. Tahap keempat melakukan proses implementasi yang akan dilakukan oleh programer. Tahap kelima anggota peneliti akan melakukan pengujian sistem. 
Tahap keenam membuat kesimpulan dan penelitian lanjutan oleh ketua pengusul. Gambar alur penelitian dapat dilihat pada Gambar 1.

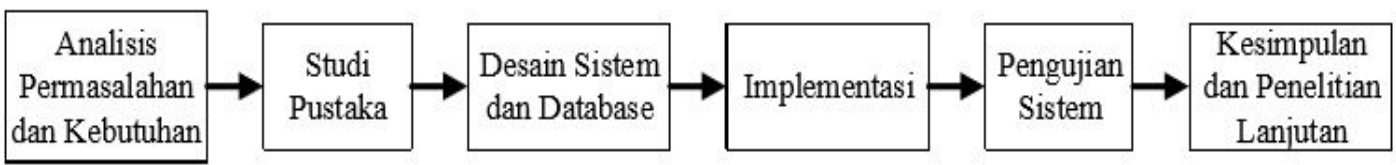

Gambar 2. Alur Penelitian

Pertama metode observasi dalam penelitian ini dilakukan pengamatan secara direct/angsung ke tempat penelitian dimana peneliti mencatat segala kebutuhan yang diperlukan dalam merancang bangun sistem [10]. Selanjutnya metode kepustakaan merupakan kegiatan pengumpulan data pustaka, membaca, dan mencatat hal-hal terkait penelitian rancang bangun sistem surveillance berbasis pengenalan wajah. Kemudian Pengumpulan data harus dilakukan berdasarkan teori yang relevan sehingga dapat mendukung penelitian yang akan dibuat dan membantu dalam memperoleh data mengenai metode yang digunakan. Dalam hal ini adalah metode eigenface dan distance classifier.

\section{Gambaran Umum Sistem}

Secara garis besar sistem surveillance yang dibuat dengan struktur seperti gambar 2, sistem surveillance nantinya diharapkan dapat memperhatikan prilaku dari seseorang, objek atau proses dalam sistem yang mengharapkan ditemukannya suatu kejadian tertentu pada sistem yang tentunya bertujuan untuk keamanan atau kontrol sosial yang berbasis pengenalan wajah.

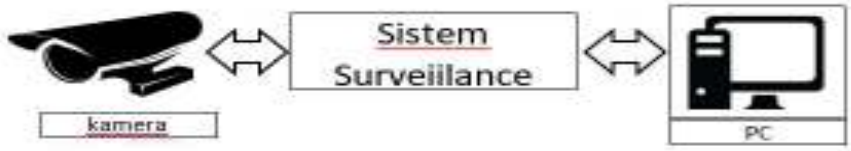

Gambar 3. Gambaran Umum Sistem

Dimana sistem yang akan dibuat memiliki beberapa tahapan dimana yang pertama dilakukan deteksi wajah, selanjutnya wajah yang telah dideteksi di reduksi dimensi dan ekstraksi ciri wajah akan menghasilkan feature ciri wajah lalu masuk sebagai database wajah. Nantinya database wajah akan di klasifikasi dengan wajah yang masuk. Dilakukan proses training wajah sebelumnya untuk dijadikan database dan di klasifikasi dengan wajah yang baru sehingga dapat dikenali.

\section{Hasil dan Pembahasan}

Berikut merupakan proses operasi sistem Surveillance yang dilakukan pada salah satu Lab yang ada pada STMIK STIKOM Indonesia dimana dilakukan percobaan pada laboratorium kampus. Proses operasi sistem dapat dilihat pada Gambar 3.

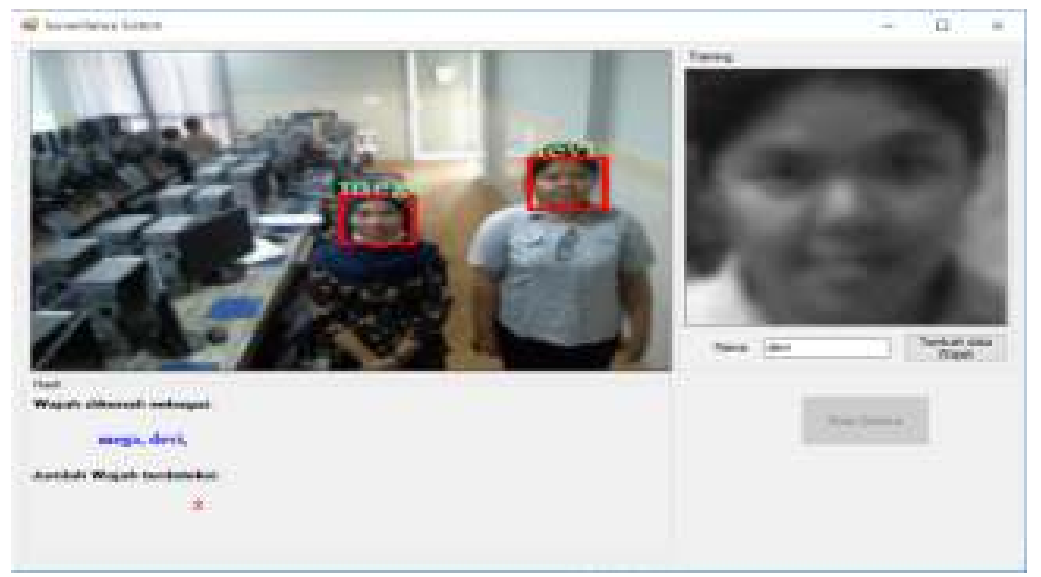

Gambar 4. Gambar sistem surveillance berjalan 


\section{Database Sistem}

Database merupakan aspek yang sangat penting dalam menentukan hasil dari proses pengujian[11]. Adapun database sistem yang digunakan pada penelitian ini yaitu database wajah yang diambil pada STMIK STIKOM Indonesia yaitu database mahasiswa STIKI sebanyak 50 orang dimana masing wajah di training sebanyak 20 wajah dengan ekpresi berbeda sehingga memperoleh data wajah sebanyak 1000 wajah. Beberapa wajah dapat dilihat pada gambar 4 .
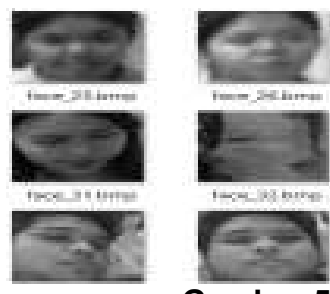

Gambar 5. Database Wajah Sistem Surveillance

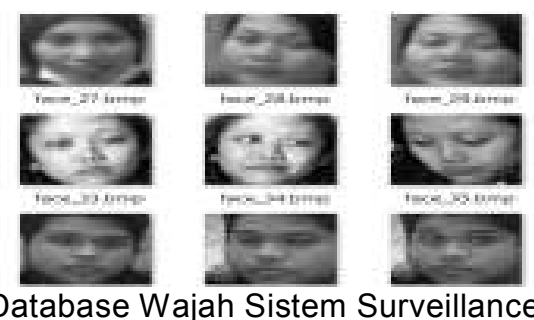

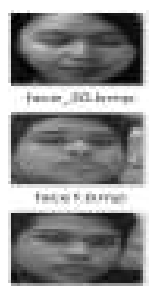

\section{Pengujian Sistem}

Adapun pengujian sistem yang dilakukan pada penelitian ini yaitu seberapa jauh sistem dapat mendeteksi wajah serta tingkat akurasinya adapun scenario pengujian yang dibuat berdasarkan metode pengujian blackbox [12], dapat dilihat pada tabel 1.

Tabel 1. Pengujian Sistem Deteksi Wajah berdasarkan Jarak

Nama Parameter yang digunakan

\begin{tabular}{ccccccc}
\cline { 2 - 6 } User & Jarak & $\begin{array}{c}\text { Deteksi } \\
\text { wajah }\end{array}$ & Jarak & $\begin{array}{c}\text { Deteksi } \\
\text { wajah }\end{array}$ & Jarak & $\begin{array}{c}\text { Deteksi } \\
\text { wajah }\end{array}$ \\
\hline Devi & $1 \mathrm{~m}$ & Berhasil & $1,5 \mathrm{~m}$ & berhasil & $2 \mathrm{~m}$ & Berhasil \\
\hline Putri & $1 \mathrm{~m}$ & Berhasil & $1,5 \mathrm{~m}$ & Berhasil & $2 \mathrm{~m}$ & Berhasil \\
\hline Mega & $1 \mathrm{~m}$ & Berhasil & $1,5 \mathrm{~m}$ & Berhasil & $2 \mathrm{~m}$ & Berhasil \\
\hline Devi & $2,5 \mathrm{~m}$ & Berhasil & $3 \mathrm{~m}$ & berhasil & $3,5 \mathrm{~m}$ & Gagal \\
\hline Putri & $2,5 \mathrm{~m}$ & Berhasil & $3 \mathrm{~m}$ & Berhasil & $3,5 \mathrm{~m}$ & Gagal \\
\hline Mega & $2,5 \mathrm{~m}$ & Berhasil & $3 \mathrm{~m}$ & Berhasil & $3,5 \mathrm{~m}$ & Gagal
\end{tabular}

Adapun skenario pengujian yang dilakukan pada tabel 1. dilakukan pengujian masing masing sebanyak 10 kali pada setiap jarak yang ada pada tabel kemudian disimpulkan pada tabel yang telah dibuat pada tabel 1. adapun total pengujian yang dilakukan untuk proses deteksi wajah dengan sistem surveillance yang telah dibangun sebanyak 180 x percobaan dimana masing masing 10 kali untuk jarak 1 meter, 10 kali untuk jarak 1,5 meter, 10 kali untuk jarak 2 meter, 10 kali untuk jarak 2,5 mater,10 kali pada jarak 3 meter dan 10 x pada jarak 3,5 meter pada setiap mahasiswi yang ditulis pada tabel 1. pada pengujian tersebut dilakukan dengan wajah tetap menghadap ke kamera, namun jika tidak menghadap kamera diperlukan proses training dengan maksimal kemiringan tertentu untuk dapat dikenali proses deteksi wajah yang telah dibangun.

Tabel 2. Pengujian sistem Berdasarkan jarak dan akurasi

\begin{tabular}{ccccccc}
\hline \multirow{2}{*}{$\begin{array}{c}\text { Nama } \\
\text { User }\end{array}$} & \multicolumn{5}{c}{ Parameter yang digunakan } \\
\cline { 2 - 7 } & Jarak & Akurasi & Jarak & Akurasi & Jarak & akurasi \\
\hline Devi & $1 \mathrm{~m}$ & $90 \%$ & $1,5 \mathrm{~m}$ & $90 \%$ & $2 \mathrm{~m}$ & $80 \%$ \\
\hline Putri & $1 \mathrm{~m}$ & $80 \%$ & $1,5 \mathrm{~m}$ & $80 \%$ & $2 \mathrm{~m}$ & $80 \%$ \\
\hline Mega & $1 \mathrm{~m}$ & $90 \%$ & $1,5 \mathrm{~m}$ & $80 \%$ & $2 \mathrm{~m}$ & $90 \%$ \\
\hline
\end{tabular}




\begin{tabular}{ccccccc}
\hline Devi & $2,5 \mathrm{~m}$ & $70 \%$ & $3 \mathrm{~m}$ & $60 \%$ & $3,5 \mathrm{~m}$ & Gagal \\
\hline Putri & $2,5 \mathrm{~m}$ & $80 \%$ & $3 \mathrm{~m}$ & $60 \%$ & $3,5 \mathrm{~m}$ & Gagal \\
\hline Mega & $2,5 \mathrm{~m}$ & $70 \%$ & $3 \mathrm{~m}$ & $70 \%$ & $3,5 \mathrm{~m}$ & Gagal \\
\hline
\end{tabular}

Skenario pengujian yang dilakukan berdasarkan jarak dan tingkat akurasi tabel 2 yaitu user dicoba berada pada jarak tertentu kemudian dilakukan pengenalan wajah, akurasi akan meningkat jika wajah yang dideteksi menyatakan identitas nama yang sesuai dengan wajah user, hasil akurasi diperoleh dengan cara sebagai berikut :

$$
\text { akurasi totalpengujianangdianggapenar } x 100 \mathrm{c}
$$

Pengujian dilakukan sebanyak 10 kali pada masing masing jarak oleh setiap user sehingga dilakukan pengujian sebanyak 900 kali dan diperloleh hasil pengujian seperti yang terdapat pada tabel 2.

\section{Analisis Data dan Pengujian Sistem}

Adapun analisis yang dilakukan pada penelitian ini berdasarkan hasil pengujian yang telah didapat saat proses pengujian sistem pada tabel 1 dan 2 adalah :

1. Semakin banyak proses training wajah yang bervariasi (berbagai ekspresi wajah seperti senyum, tertawa, cemberut dan sebagainya) akan meningkatkan akurasi pengenalan wajah dari sistem surveillance yang dibuat.

2. Jarak antara kamera dengan user yang akan dikenali sangat mempengaruhi tingkat akurasi dari pengenalan wajah user.

3. Jarak maksimal untuk sistem dapat melakukan deteksi wajah adalah 3 meter lebih dari jarak tersebut sistem tidak dapat mendeteksi wajah, sehingga dibutuhkan suatu metode baru yang dapat mengenali wajah dengan jarak yang lebih jauh.

\section{Kesimpulan}

Adapun kesimpulan dari sistem Surveillance yang telah berhasil dirancang yaitu :

1. Rancang bangung sistem Surveillance telah berhasil diselesaikan dan memperoleh akurasi yang cukup baik terutama pada jarak 1 meter sampai 2 meter.

2. Jarak antara kamera dengan user yang akan dikenali sangat mempengaruhi tingkat akurasi dari pengenalan wajah user.

3. Jarak maksimal untuk sistem dapat melakukan deteksi wajah adalah 3 meter lebih dari jarak tersebut sistem tidak dapat mendeteksi wajah.

\section{Daftar Pustaka}

[1] I. N. T. A. Putra and A. Harjoko, "Pengenalan Wajah Berbasis Mobile Menggunakan Fisherface dan Distance Classifier," J. Sains dan Teknol., vol. 7, no. 1, pp. 135-145, 2018.

[2] S. R. Wurdianarto, S. Novianto, and U. Rosyidah, "Perbandingan Euclidean Distance Dengan Canberra Distance Pada Face Recognition," Techno.COM, vol. 13, no. 1, pp. 31-37, 2014.

[3] M. D. U. M. Ishak, "Pengenalan Pola Wajah Menggunakan Webcam Untuk Absensi dengan Metode Wavelet," vol. 12, no. 2, pp. 95-108, 2013.

[4] Fandiansyah, J. Y. Sari, and I. P. Ningrum, "Pengenalan Wajah Menggunakan Metode Linear Discriminant Analysis dan k Nearest Neighbor," vol. 11, no. June, pp. 1-9, 2017.

[5] A. Suryadi, "Sistem Pengenalan Wajah Menggunakan Metode Principal Component 
Analysis ( Pca ) Dengan Algoritma Fuzzy C-Means ( Fcm )," Mosharafa, vol. 4, no. 2, pp. 58-65, 2015.

[6] I. N. T. A. Putra, I. B. G. Dwidasmara, and I. G. S. Astawa, "Perancangan Dan Pengembangan Sistem Absensi Realtime Melalui Metode Pengenalan Wajah,” vol. 3, no. 2, pp. 450-467, 2014.

[7] A. Hendrotriatmoko, S. Hadi, and H. S. Dachlan, "Penggunaan Metode Viola-Jones dan Algoritma Eigen Eyes dalam Sistem Kehadiran Pegawai," vol. 8, no. 1, pp. 41-46, 2014.

[8] Paul Viola Michael Jones, "Robust Real-time Object Detection," Second Int. Work. Stat. Comput. Theor. Vis. - Model. Learn. Comput. Sampl., 2001.

[9] R. Wiryadinata, U. Istiyah, R. Fahrizal, P. Priswanto, and S. Wardoyo, "Sistem Presensi Menggunakan Algoritme Eigenface dengan Deteksi Aksesoris dan Ekspresi Wajah," J. Nas. Tek. Elektro dan Teknol. Inf., vol. 6, no. 2, pp. 222-229, 2017.

[10] I. N. T. A. Ira Zulfa, Putra, "Sistem Pengambilan Keputusan Untuk Penerimaan Pegawai Baru PT.PLN (Persero) Wilayah Aceh Dengan Metode Heuristik," J. Ilmu Komput., vol. 11, no. 2, p. 109, 2018.

[11] I. N. Tri, A. Putra, and K. S. Kartini, "Rancang Bangun Sistem Informasi Eksekutif pada STMIK STIKOM Indonesia," Int. J. Nat. Sci. Eng., vol. 3, no. 3, pp. 122-129, 2019.

[12] I. N. T. A. Putra, "Pengembangan Sistem Inventaris Berbasis Qr Code Menggunakan Web Service Pada Bidang Sarana Dan Prasarana Stmik Stikom Indonesia," J. Nas. Pendidik. Tek. Inform., vol. 7, no. 3, p. 315, 2019. 